\title{
Agminated blue nevus - Case report ${ }^{*}$
}

\author{
Alice Paixão Lisboa ${ }^{1}$ \\ Renata Leite Pedreira ${ }^{1}$ \\ Daniel Lago Obadia ${ }^{1,2}$
}

\author{
Keline Jácome Silvestre ${ }^{1}$ \\ Natália Ribeiro de Magalhães Alves ${ }^{1}$ \\ Luna Azulay-Abulafia ${ }^{1,3,4}$
}

DOI: http:/ / dx.doi.org/10.1590/abd1806-4841.20164448 Abstract: Blue nevi are benign melanocytic lesions located in the deeper reticular dermis, consequence of failure of melanocytic
migration into the dermal-epidermal junction from the neural crest. Lesions are usually asymptomatic and solitary, but may
present in a multiple or agminated (grouped) pattern. The agminated subtype is formed when bluish-pigmented lesions
cluster together in a well-defined area. Lesions can be flat or raised. We report the case of a patient who presented multiple
bluish macules (1-3 mm in diameter) grouped on the left upper back. Dermoscopy and anatomic pathological examination
were consistent with blue nevus.

Keywords: Melanocytes; Nevus, Blue; Nevi and Melanomas

\section{INTRODUCTION}

Blue nevi are benign melanocytic lesions located in the deeper reticular dermis, consequence of failure of melanocytic migration into the dermal-epidermal junction from the neural crest. ${ }^{1}$ The blue color is caused by the Tyndall effect, when incident light on the highly pigmented deep melanocytes refracts and scatters. ${ }^{2}$ Nevi are usually acquired and usually begin in childhood and adolescence. They are characterized by a bluish or dark-bluish dermal pigmentation area formed by aberrant collections of benign functioning melanocytes. Lesions are usually asymptomatic and solitary, but may present in a multiple or agminated (grouped) pattern., The term "agminated" comes from the Latin word agminis, which means army, troop. ${ }^{5}$

The agminated subtype is formed when bluish-pigmented lesions cluster together in a well-defined area $\leq 10 \mathrm{~cm}$. Lesions can be flat or raised. ${ }^{1}$ The first case of agminated blue nevus was reported by Upshaw et al. in 1947. Since then, authors have used different terms - plaque-type blue nevus or eruptive blue nevus - to refer to the condition in the few published cases. ${ }^{4,6}$

Although the pathogenesis of agminated blue nevus is unknown, some reports suggest that skin traumas or sunburn could stimulate the proliferation of melanocytes., ${ }^{2,7}$ Lesions can arise on normal skin or on lentiginous macules. Histologically, the lesions are characterized by highly-pigmented dermal dendritic melanocytes and melanophages. ${ }^{1}$
Dermoscopy reveal a smooth blue area without structure, absence of pigmented network, globules and dots. Edges are usually irregular and may fade into the surrounding skin. ${ }^{8}$

Differential diagnosis should include plaque-type multiple vascular tumors, agminated Spitz nevus and metastatic melanoma. ${ }^{5}$

Although the evolution of agminated blue nevus is benign, biopsy is recommended to rule malignant transformation given the rarity of the lesions.,

\section{CASE REPORT}

We report a 64-year-old male patient with Darier's disease on acitretin $30 \mathrm{mg} /$ day presented to our clinic for routine dermatological consultation. Dermatological examination revealed multiple 1-3mm bluish stains, clustered together in an area of $7 \times 5 \mathrm{~cm}$ on the left upper back (Figures 1 and 2). Since the lesions were asymptomatic, the patient was unable to report the time evolution of the lesions.

Dermatoscopic examination revealed homogeneous bluish or grayish nevi presented with no structures. We observed no pseudopods or radial striations (Figure 3).

An incisional biopsy of the lesion was performed to clarify the diagnosis.

Histopathological examination showed brownish pigmented fusiform and oval-shaped melanocytic cells in the upper and deeper dermis, not forming nests but arranged in bundles and fusiform and oval-shaped melanocytic cells compatible with blue nevus (Figures 4, 5 and 6).

Received on 08.02.2015.

Approved by the Advisory Board and accepted for publication on 05.09.2015.

* Work performed at Hospital Universitário Pedro Ernesto - Universidade do Estado do Rio de Janeiro (HUPE-UERJ) - Rio de Janeiro (RJ), Brazil. Financial Support: None.

Conflict of Interest: None.

Universidade do Estado do Rio de Janeiro (UERJ) - Rio de Janeiro (RJ), Brazil.

Universidade do Grande Rio (Unigranrio) - Rio de Janeiro (RJ), Brazil.

Universidade Estácio de Sá - Rio de Janeiro (RJ), Brazil.

Instituto de Dermatologia Professor Rubem David Azulay - Santa Casa da Misericórdia do Rio de Janeiro (IDPRDA-SCMRJ) - Rio de Janeiro (RJ), Brazil. 


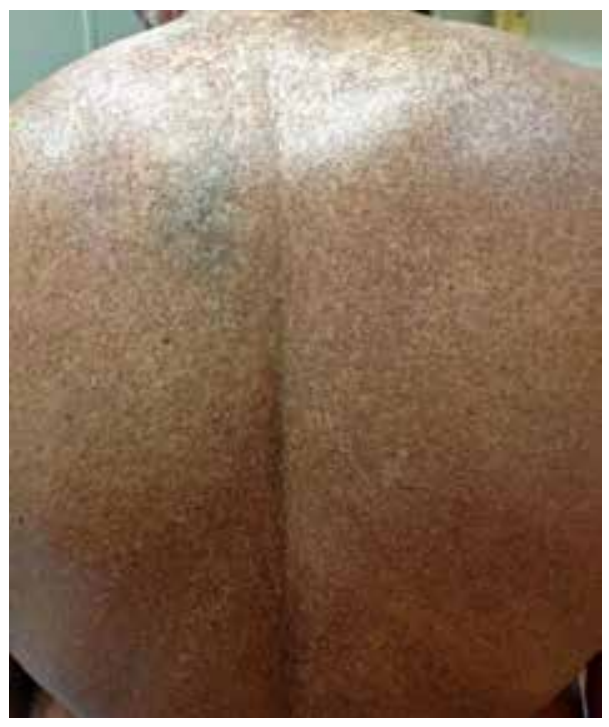

FIGURE 1:

Bluish pigmented lesions clustered together in area of $7 \times 5 \mathrm{~cm}$ on the upper back

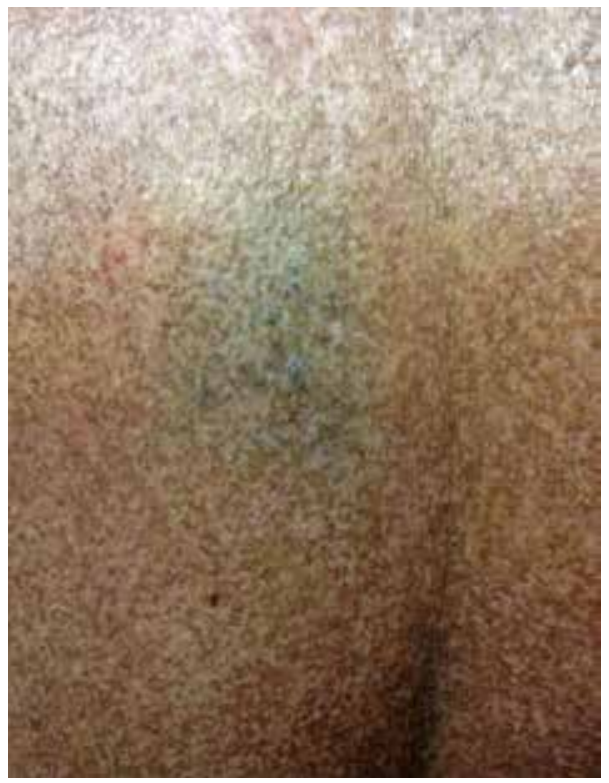

FIGURE 2:

Agminated

blue nevus

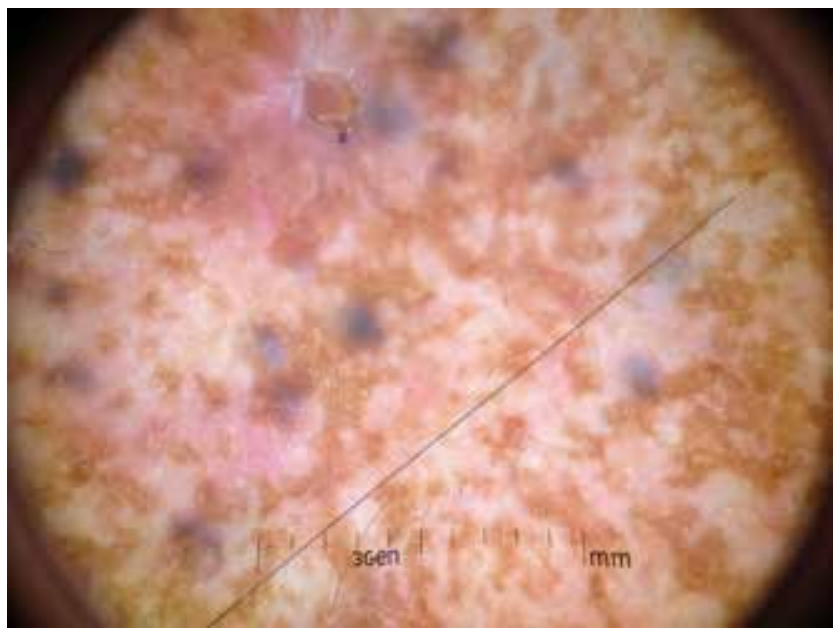

FIGURE 3: Dermoscopy revealed homogeneous bluish or grayish nevus with no structures. No pseudopods or radial striations reported

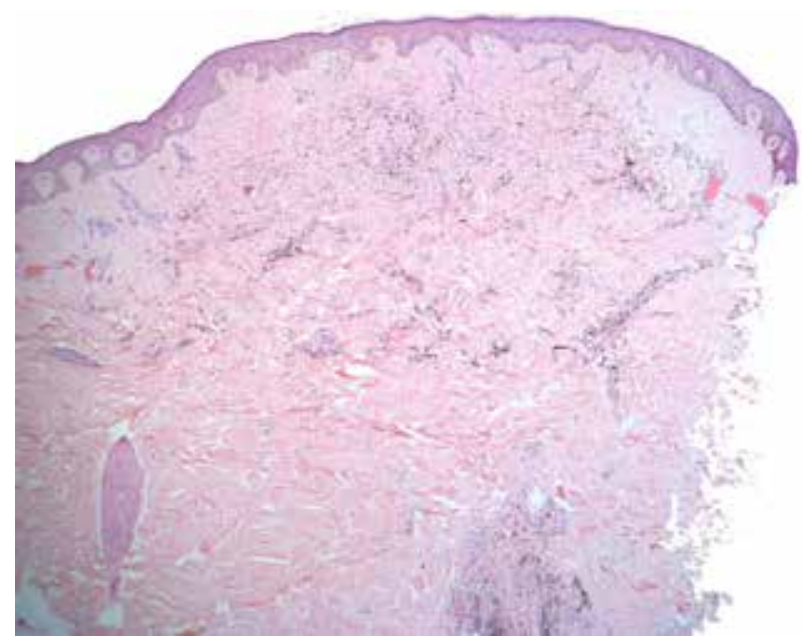

Figure 4: Blue nevus (H\&E, 40x magnification)

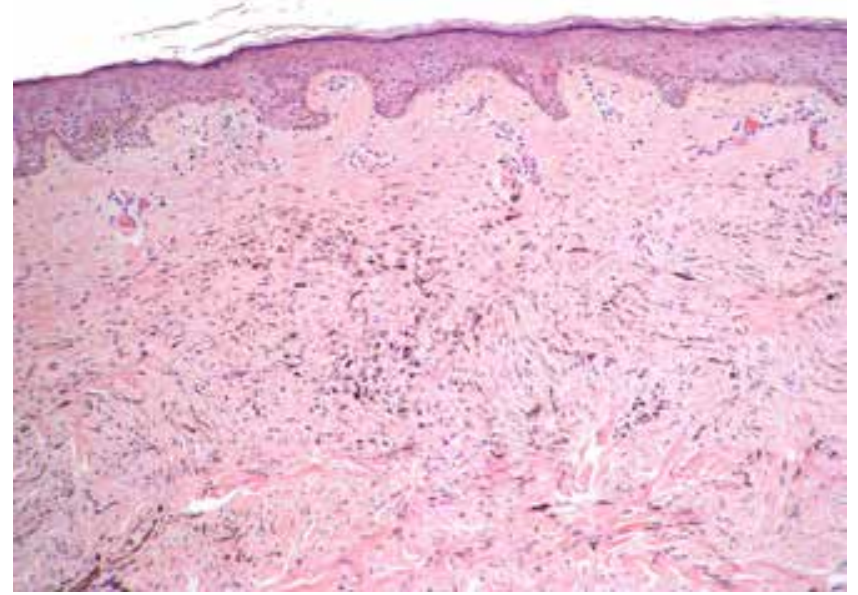

FIGURE 5: Brownish pigmented fusiform and oval-shaped melanocytic cells in the upper and deeper dermis, not forming nests but arranged in bundles H\&E, 100x magnification

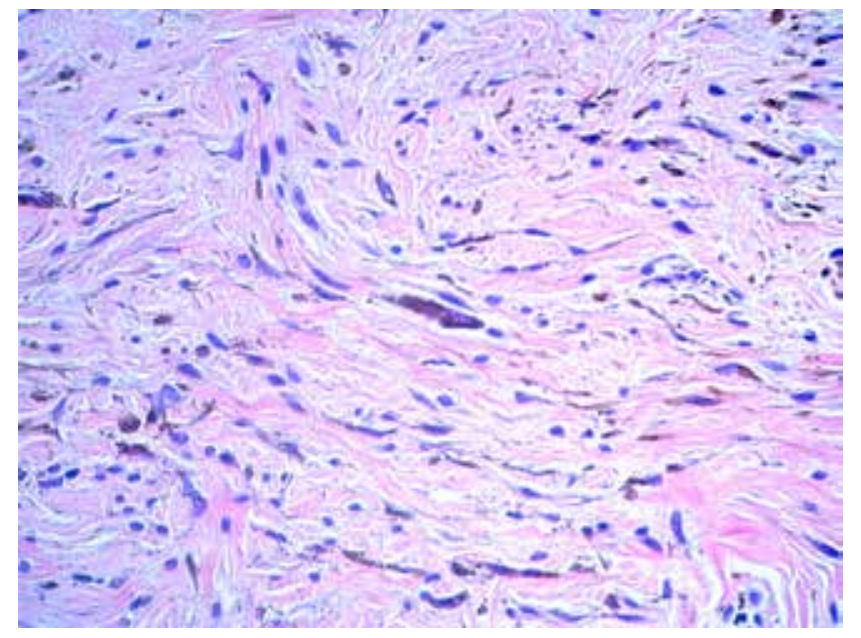

Figure 6: Fusiform and oval-shaped melanocytic cells H\&E, 400x magnification 


\section{DISCUSSION}

Cases of agminated blue nevus are rarely mentioned in the literature, probably underreported because of the asymptomatic nature of the disease. This is why we report a case of agminated blue nevus on the back of a patient with Darier's disease.
We emphasize the importance of a detailed dermatological examination in patients. Considering that our patient was unaware of the existence of the lesions, diagnosis should not be limited to patient's complaints.

Although agminated blue nevi are usually benign, our patient is being followed up with periodic dermoscopic examination.]

\section{REFERENCES}

1. Lapresta A, Mollejo M, García-Almagro D. Cases for diagnosis. Bluish papules on the forehead. Actas Dermosifiliogr. 2011;102:219-20.

2. Barnhill RL, Rabonivitz H. Neoplasias melanocíticas benignas. In: Bolognia JL Jorizzo J, Rapini RP, editores. Dermatologia. 2. ed. Rio de Janeiro: Elsevier; 2011. p.1713-1744.

3. Hsiao GH, Hsiao CW. Plaque-type blue nevus on the face: a variant of Ota's nevus? J Am Acad Dermatol. 1994;30:849-51.

4. Upshaw BY, Ghormley RK, Montgomery H. Extensive blue nevus of JadassohnTieche. Surgery. 1947;22:761-5.

5. Jovani SG, Caus JM, Ruiz YF, Krüger M, Schmidt JS, Carazo AM , et al. Nevo azul en placa. Actas Dermosifiliogr. 2002;93:594-6.

6. Chen T, Kurwa HA, Trotter MJ, Haber RM. Agminated blue nevi in a patient with dermatomyositis. J Am Acad Dermatol. 2013;68:e52-3.

7. Ying Wen S. Plaque-type blue nevus. Review and an unusual case. Acta Derm Venereol.1997;77:458-9

8. Barcaui C, Ferreira CMM, Piñeiro-Maceira J. Lesões melanocíticas benignas. In: Ferreira CMM, Barcaui C, Piñeiro-Maceira J. Atlas de Dermatoscopia. Aplicação clínica e correlação histopatológica. Rio de Janeiro: Dilivros; 2011. p. 79-122
MAILING ADDRESS:

Alice Paixão Lisboa

Boulevard 28 de setembro, 77

Vila Isabel

20551-030 Rio de Janeiro, RJ, Brazil

E-mail:alicepaixaolisboa@yahoo.com

How to cite this article: Lisboa AP, Silvestre KJ, Pedreira RL, Alves NRM, Obadia DL, Azulay-Abulafia L. Agminated blue nevus - Case report. An Bras Dermatol. 2016;91(5):658-60. 